КОНЦЕПЦІЯ ІНТЕГРОВАНОГО РОЗВИТКУ МІСТ: ЄВРОПЕЙСЬКИЙ ДОСВІД ТА МОЖЛИВОСТІ ЙОГО ЗАСТОСУВАННЯ В УКРАÏHI Рейк'явік. кількості пристроїв. положень Свропейського Союзу.
ГОЛОВНЯ О.М., доктор економічних наук, доцент кафедри менеджменту зовнішньоекономічної діяльності, готельно-ресторанної справи та туризму, Вінницький національний аграрний університет (м. Вінниця)

КОНДРАТОВА М.В., кандидат педагогічних наук, директор Відокремленого структурного підрозділу «Немирівський фаховий коледж будівництва, економіки та дизайну Вінницького національного аграрного університету" (м. Немирів)

Авторами статті досліджено, щзо провідною формою територіальної та соиіальноекономічної організачії сучасного суспільства є міста. Водночас міста виступають драйверами соціально-економічного розвитку, політичного піднесення і соціального прогресу та матимуть безсумнівне значення для формування конкурентоспроможності краӥн світу.

Встановлено, щчо одним із документів, який розроблений за участю представників загальноєвропейських інтересів та сприяє інтегрованому розвитку міст, $\epsilon$ Лейпцизька хартія «Міста Свропи на шляху сталого розвитку». Інтегрованому розвитку міст допомагає практика партисипативного управління. Партисипативне управління набуває актуальності в умовах децентралізачії та розвитку громад, зокрема, партисипативне бюджетування, щуо полягає у можливості мешканців міста брати участь у прийнятті рішення щуодо того, як розподілити певну частину бюджету.

Проаналізовано, що існує велика кількість міжнародних індексів для кількісної та якісної оцінки розвитку міст, які дозволяють дослідити тенденції й оцінити вплив політичних рімень і кроків, які приймаються в межах міст для покращення добробуту жителів. Досліджено категорію міст - «розумне» місто (Smart City). Встановлено, щуо в рейтингу Smart Cities Index перші місия займають Нью-Йорк, Лондон, Париж, Токіо,

Серед умов розвитку інтегрованих міст на основі конщепції «Smart City» виділено наступне: впровадження мереж покоління 5G, суцільне покриття територій $i$ доступ до інтернету у важкодоступних місиях, безперебійна одночасна робота в мережі великої

Співробітництво та партнерство з європейськими товариствами й організаціями допомагає украӥнським містам у їх інтегрованому розвитку. Теоретико-методологічною основою дослідження стали наукові прачі вітчизняних та закордонних авторів із питань інтегрованого розвитку міст на основі європейського досвіду та керівних принципів $i$

Ключові слова: сталий розвиток, соціально-економічний розвиток, інтегрований розвиток, «розумне» місто, місцеве управління, міське населення.

Табл.: 5. Рис.: 2. Літ.: 17. 


\section{THE CONCEPT OF INTEGRATED CITY DEVELOPMENT: EUROPEAN EXPERIENCE AND POSSIBILITIES OF ITS IMPLEMENTATION IN UKRAINE}

GOLOVNYA Olena, Doctor of Economic Sciences, Associate Professor of the Department of International Management, Hotel and Restaurant Business and Tourism, Vinnytsia National Agrarian University

(Vinnytsia)

KONDRATOVA Maryna, Candidate of Pedagogical Sciences, Director of the Separate Structural Subdivision «Nemyriv Professional College of Construction, Economics and Design of Vinnytsia National Agrarian University"

(Nemyriv)

The authors investigate that the leading form of territorial and socio-economic organization of modern society are cities. At the same time, cities act as drivers of socio-economic development, political prosperity and social progress and will undoubtedly be important for the formation of competitiveness in the world.

It is established that one of the documents, which was developed with the participation of representatives of common European interests and promotes to integrated urban development, is the Leipzig Charter "Cities of Europe on the path to sustainable development». The practice of participatory management helps integrated urban development. Participatory management becomes relevant in the context of decentralization and community development, in particular participatory budgeting, which is the opportunity for city residents to participate in decisionmaking on how to allocate a certain part of the budget.

It is analysed, that plenty of international indexes is for the quantitative and quality estimation of development of cities, that allow to explore tendencies and estimate influence of political decisions and steps that is accepted within the limits of cities for the improvement of welfare of habitants. A category - "Smart City» is investigated. It is set that in rating of Smart Cities Index the first places occupy New York, London, Paris, Tokyo, Reykjavik.

Among the terms of development of the integrated cities on the basis of conception of «Smart City" the following is highlighted: introduction of networks of generation 5G, continuous coverage of territories and access to the internet in difficult of access places, trouble-free simultaneous work in the network of enormous number of devices.

A collaboration and partnership with European societies and organizations help the Ukrainian cities in their integrated development. The theoretical and methodological basis of the study has become the scientific works of Ukrainian and foreign authors on integrated urban development based on European experience and guidelines and provisions of the European Union.

Keywords: sustainable development, socio-economic development, integrated development, «smart city», local government, urban population.

Tabl.: 5. Fig.: 2. Ref.: 17.

КОНЦЕПЦИЯ ИНТЕГРИРОВАННОГО РАЗВИТИЯ ГОРОДОВ: ЕВРОПЕЙСКИЙ ОПЫТ И ВОЗМОЖНОСТИ ЕГО ПРИМЕНЕНИЯ В УКРАИНЕ 
ГОЛОВНЯ Е.М., доктор экономических наук, доцент кафедры менеджмента внешнеэкономической деятельности, гостинично-ресторанного дела и туризма, Винницкий национальный аграрный университет (2. Винница)

\author{
КОНДРАТОВА М.В., \\ кандидат педагогических наук, директор \\ Обособленного структурного подразделения «Немировский \\ профессиональный колледж строительства, экономики и дизайна \\ Винницкого национального аграрного университета» \\ (2. Немиров)
}

\begin{abstract}
Авторами статьи исследовано, что ведущей формой территориальной и сочиальноэкономической организации современного общества являются города. При этом города выступают драйверами сочиально-экономического развития, политического подъема и сочиального прогресса и имеют несомненное значение для формирования конкурентоспособности стран мира.
\end{abstract}

Установлено, что одним из документов, разработанных при участии представителей общеевропейских интересов и способствующих интегрированному развитию городов является Лейпцигская хартия «Города Европь на пути устойчивого развития». Интегрированному развитию городов помогает практика партисипативного управления. Партисипативное управление приобретает актуальность в условиях децентрализаџии и развития общин, в частности партисипативное бюджетирование заключается в возможности жителей города участвовать в принятии решения о том, как распределить определенную часть бюджета.

Проанализировано, что существует большое количество международных индексов для количественной и качественной оченки развития городов, которые позволяют исследовать тенденции и оченивать влияние политических решений и шагов, принимаемых в пределах городов для улучшения благосостояния жителей. Исследовано категорию «умный» город (Smart City). Установлено, что в рейтинге Smart Cities Index nервые места занимают Нью-Йорк, Лондон, Париж, Токио, Рейкьявик.

Среди условий развития интегрированных городов на основе концепџии "Smart City» выделено следующее: внедрение сетей поколения 5G, сплошное покрытие территорий $u$ доступ к интернету в труднодоступных местах, бесперебойная одновременная работа $в$ сети огромного числа устройств.

Сотрудничество и партнерство с европейскими обществами и организациями помогает украинским городам в их интегрированном развитии. Теоретикометодологической основой исследования стали научные труды отечественных $u$ зарубежных авторов по вопросам интегрированного развития городов на основе европейского опыта и руководящих принщипов и положений Европейского Союза.

Ключевые слова: устойчивое развитие, социально-экономическое развитие, интегрированное развитие, «умный» город, местное управление, городское население.

Табл.: 5. Рис.: 2. Лит.: 17.

Постановка проблеми. Сьогодні міста $є$ провідною формою територіальної, політичної та соціально-економічної організації сучасного 
суспільства. Близько 78\% європейців проживають у містах, 85\% ВВП ЄС також генерується у містах [12].

Україна має давні традиції централізованого управління та регулювання місцевого розвитку територій з боку уряду. Завдяки Угоді про асоціацію 3 Європейським Союзом, яка була ратифікована у вересні 2014 року, на Україну також поширюється дія Лейпцизької хартії із ії прагненням до розширення самоврядування, прав і можливостей міст.

Лейпцизька хартія (2008 року) «Міста Європи на шляху сталого розвитку» - це документ, розроблений за участю представників різних суспільних груп загальноєвропейських інтересів. Усвідомлюючи всі загрози, виклики та шанси, й беручи до уваги різні культурні, історичні, економічні, соціальні, політичні та екологічні аспекти в розвитку європейських міст, відповідальні за питання міського розвитку міністри держав-учасниць узгодили спільні позиції, принципи й стратегії у сфері політики міського розвитку $[11$, c. 9].

Лейпцизька хартія визначає, що сталий розвиток міст має гарантувати економічне процвітання, соціальну рівновагу i здорове навколишнє середовище. Вона рекомендує зосередити розвиток на містах, отримати більше користі від використання підходів політики інтегрованого розвитку міст. На розвиток міста впливає багато взаємозалежних факторів, відтак виникає потреба у чіткому та цілісному плануванні та інтегрованому підході до розвитку міст. Такий підхід успішно був використаний у розвитку великих європейських міст й невеликих містечок.

Аналіз останніх досліджень і публікацій. Науково-теоретичним та практичним аспектам місцевого розвитку присвячені численні наукові дослідження Г.М. Калетніка [10], Т.В. Колесник [10], К.Л. Маркевич [12], Л.М. Пронько [14], В.Я. Чевганової [16] та багатьох інших. Проте, сьогодні, для ефективного вирішення проблеми безпечного та екологічного розвитку міст, необхідно використовувати інтегрований підхід із урахуванням сучасних вимог сталого розвитку країни.

Формулювання цілей статті. Метою дослідження $\epsilon$ наукове обгрунтування теоретичних i практичних засад розвитку міст на основі європейського досвіду з використанням інтегрованого підходу, провідне місце в якому займає концепція «розумних» міст.

Виклад основного матеріалу дослідження. 3 кожним роком більш очевидним у всьому світі $\epsilon$ вихід міст за локальні межі свого географічного положення - на міжнародний рівень, - здобувши владу та репутацію у таких глобалізованих галузях, як боротьба із серйозними наслідками змін клімату, управлінням міграційними процесами та стрімким розвитком цифрових технологій.

За даними Департаменту економічних і соціальних питань ООН (United Nations Department of Economic and Social Affairs) [7], у 1950-х роках у містах проживало близько 30\% світового населення, у 2014 р. цей відсоток зріс до 55\% 
(3,5 млрд осіб) i, як очікується, продовжить зростати, досягши 68\% у 2050 р. (рис. 1). Європейський досвід розвитку конкурентоспроможних громад доводить, що для формування підходів інтегрованого розвитку міст важливо спиратись на стратегічні документи, в яких визначаються бачення (візія), цілі, завдання та проєкти розвитку міст. Базуючись на основних положеннях Лейпцизької хартії та активно використовуючи партисипативні практики (залучення громадян), міста розробляють та впроваджують концепцію інтегрованого розвитку.

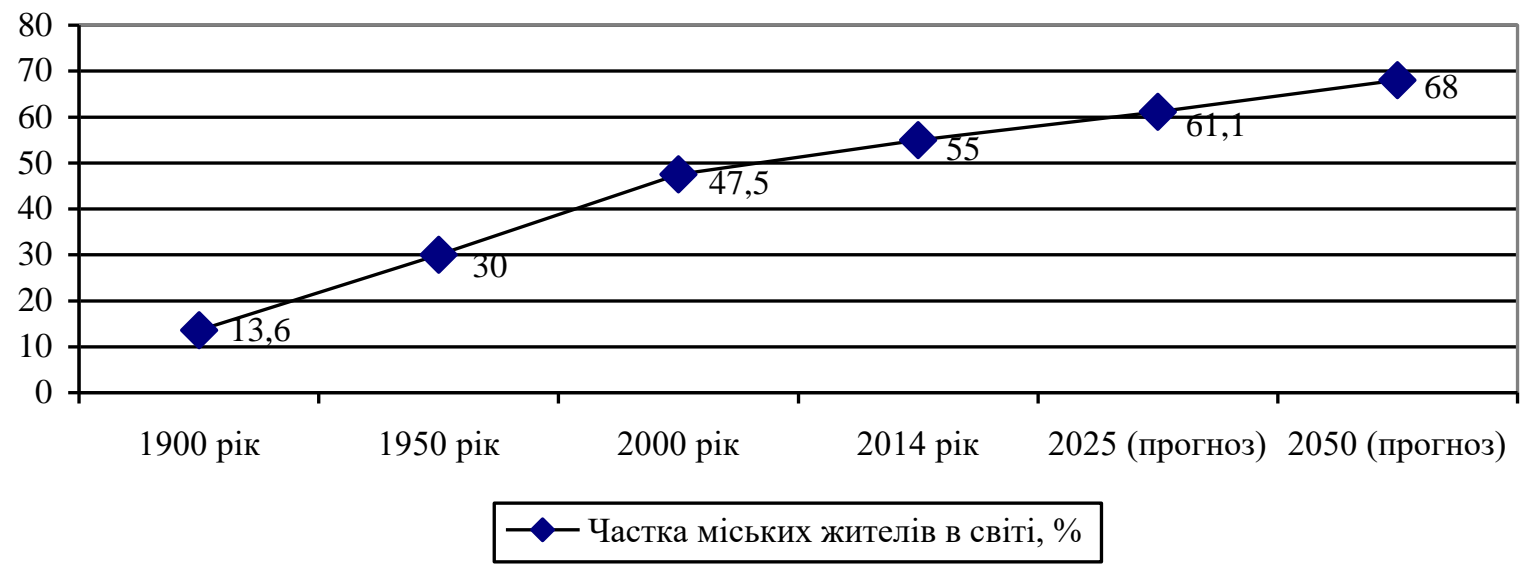

\section{Рис. 1. Частка міських жителів у світі, \%}

Джерело: складено авторами за [4]

Ці документи, хоч і є неформальним плануванням (не визначені, за законом, як обов'язкові документи містобудівної документації), однак, $\epsilon$ правовою та інформаційною основою для подальшої розробки генеральних планів міст, інвестицій у будівництво, раціонального використання територій, реалізації масштабних проєктів, організації проведення робіт із планування територій на регіональному та місцевому рівнях [9].

Фундаментальною основою формування соціально орієнтованої національної економіки має стати місцеве управління. Відповідно до Свропейської хартії місцевого самоврядування під цим поняттям розуміють право і реальну можливість органів місцевого самоврядування регламентувати значну частину публічних справ за рахунок власної відповідальності в інтересах місцевого населення.

Для покращення якості та комфортності життя населення має значення фінансовий потенціал території, фінансове забезпечення місцевих органів влади та нарощування муніципальних фінансів - сукупність грошових засобів, якими володіють органи місцевого самоврядування для вирішення соціальноекономічних завдань, які поставлені державою та місцевим населенням $[6$, c. 35].

Тому, саме інтегрований розвиток міста - це спосіб активізувати та поєднати наявні ресурси для досягнення поставлених цілей, в яких зацікавлені всі сторони. До інтегрованого розвитку міста потрібно віднести компоненти, наведені в табл. 1. 


\section{Компоненти інтегрованого розвитку міст}

\begin{tabular}{|c|c|c|c|}
\hline $\begin{array}{l}\text { № } \\
\text { 3/ח }\end{array}$ & $\begin{array}{l}\text { Критерій } \\
\text { групування } \\
\text { компонент } \\
\text { через призму } \\
\text { сталого } \\
\text { розвитку } \\
\end{array}$ & Компонента & Характеристика компоненти \\
\hline 1 & \multirow{3}{*}{$\begin{array}{l}\text { Інституційно- } \\
\text { економічний }\end{array}$} & Інституційна & $\begin{array}{l}\text { Залученість громадян до процесу прийняття рішень, активна участь } \\
\text { населення у політиці та громадському житті, прозорість та підзвітність, } \\
\text { публічні та соціальні послуги, канали оцінки та зворотного зв'язку. }\end{array}$ \\
\hline 2 & & Економічна & $\begin{array}{l}\text { Системне залучення інноваційного потенціалу в економічну діяльність, } \\
\text { ефективність, розвинений ринок праці, залученість до міжнародної } \\
\text { економічної системи. }\end{array}$ \\
\hline 3 & & Технологічна & $\begin{array}{l}\text { Формування матеріальної інноваційної інфраструктури (фонди, } \\
\text { інкубатори, офіси трансферу технологій). Необхідні навички, засоби } \\
\text { комунікації, онлайн платформи та новітні інструменти для навчання, } \\
\text { цифрові системи управління навчанням, хмарні платформи для відео й } \\
\text { аудіо конференцій та вебінарів, датчики, сенсори, комп'ютери } \\
\text { тощо. }\end{array}$ \\
\hline 4 & \multirow{4}{*}{ Соціальний } & $\begin{array}{c}\text { Людський } \\
\text { капітал }\end{array}$ & $\begin{array}{l}\text { Талант, креативність, безперервне навчання, навички, збільшення } \\
\text { ступеня активної участі всіх громадян у соціумі. }\end{array}$ \\
\hline 5 & & $\begin{array}{l}\text { Соціальний } \\
\text { капітал }\end{array}$ & $\begin{array}{l}\text { Партнерство, культурні традиції, родина, мережа, інклюзивне } \\
\text { суспільство, підвищення цифрової грамотності та компетенцій у } \\
\text { населення. }\end{array}$ \\
\hline 6 & & Спосіб життя & $\begin{array}{l}\text { Охорона здоров'я, здоровий спосіб життя, духовне збагачення, } \\
\text { культура, безпека, якість життя, навчання, туризм, соціальна єдність, } \\
\text { всебічний розвиток особистості. }\end{array}$ \\
\hline 7 & & Мобільність & $\begin{array}{l}\text { Соціальна єдність, інноваційність мислення, безпека транспортних } \\
\text { систем, немоторизовані транспортні засоби, соціальна мобільність, } \\
\text { академічна мобільність, формування мобільного фахівця, що } \\
\text { передбачає організацію освітньо-виховного середовища, яке орієнтує } \\
\text { майбутнього спеціаліста на різноплановість вибору самопрояву, } \\
\text { статусного росту, професійного розвитку, швидкої орієнтації } \\
\text { (адаптованості), прагнення активно змінити несприятливі ситуації. }\end{array}$ \\
\hline 8 & \multirow[t]{2}{*}{ Екологічний } & Довкілля & $\begin{array}{l}\text { Захист навколишнього природнього середовища, стале управління } \\
\text { ресурсами, привабливість природних умов, «розумне» використання } \\
\text { наземних та водних екосистем і запобігання втраті біорізноманіття, } \\
\text { вимірювання якості питної води. }\end{array}$ \\
\hline 9 & & $\begin{array}{c}\text { Енерго- } \\
\text { ефективність }\end{array}$ & $\begin{array}{l}\text { Енергоефективні будинки, використання розумних вуличних датчиків } \\
\text { та ліхтарів, ефективна система стічних вод та дренажу. }\end{array}$ \\
\hline
\end{tabular}

Джерело: розробка авторів

Таблиця 1 дає можливість зрозуміти, що актуальними $є$ питання поєднання компонент інтегрованого розвитку міст так, щоб у містах підвищувати якість життя населення, покращувати стан навколишнього середовища, а потреби національної економіки загалом визначалися орієнтирами соціального розвитку. Тобто, всі компоненти варто розглядати через призму сталого розвитку міст, як складової національної економіки.

Існує велика кількість міжнародних i національних інтегральних показників та індексів для кількісної та якісної оцінки соціально-економічного розвитку міст. Такі показники та індекси розробляються в рамках національних і міжнаціональних партнерств для моніторингу сталого комплексного розвитку міст. Крім того, такі індекси допомагають визначити сфери, які потребують найбільшої уваги від менеджерів і керівників міст. Найбільш відомими $є$ : The 
Sustainable Cities Index (складається консалтинговою компанією ARCADIS); European Smart Cities (Віденський технологічний університет); Cities in Motion Index (Іспанська бізнес-школа IESE); Global Power City Index (Інститут урбаністичних стратегій Меморіального фонду Японіï); Smart City Index (Центр світової конкурентоспроможності Міжнародного інституту розвитку менеджменту разом із Сінгапурським університетом технологій і дизайну) тощо.

Серед міст-лідерів за різними рейтингами можна побачити Сінгапур, Стокгольм, Відень, Лондон, Чикаго, Нью-Йорк [12, с. 348].

Інституціональна основа інтегрованого підходу до оновлення міського середовища визначена Європейською комісією шляхом пілотних проєктів, що стосуються міст. Отже, отримує подальший розвиток концепція, яка вже включає не лише оновлення районів, що знаходяться в несприятливій ситуації, але й усіх елементів міського середовища: планування, міська мобільність, транспортне моделювання, велосипедна навігація, комунальна інфраструктура, довкілля і т. д. [16, с. 10].

В основу концептуальних засад управління інтегрованим розвитком міста покладено керівні принципи та положення Свропейського Союзу, а саме: Хартія Конгресу місцевих і регіональних влад Свропи (Страсбург, 1957 р.), Європейська хартія регіонального просторового планування (Торремолінська Хартія, 1983 р.), Свропейська хартія місцевого самоврядування (Страсбург, 1985 р.), Гетеборзька стратегія сталого розвитку Свропи (Гетеборг, 2001 р.), Лейпцизька хартія сталого розвитку міста (Лейпциг, 2007 р.), Стратегія Європа2020 «Стратегія для розумного, сталого та всеохоплюючого зростання» (Брюссель, 2010 р.).

Питання розвитку міст внесено до «Порядку денного в галузі сталого розвитку до 2030 р.». У травні 2016 р. ООН прийнято нову Програму розвитку міст (Habitat III), якою формуються орієнтири зростання та розвитку міст до 2036 р. Також, у 2016 р. було затверджено Програму європейських міст (Тhe State of European Cities), яка охоплює коло питань: зменшення рівня бідності, збільшення рівня мобільності, забезпеченість житлом, розвиток циркулярної економіки, вирішення проблем змін клімату та адаптації іммігрантів.

Використання проєктних технологій інтегрованого розвитку міст $\epsilon$ одним із напрямів удосконалення стратегічного управління місцевим розвитком. Проєкт «Інтегрований розвиток міст в Україні» підтримується німецькою урядовою компанією «Deutsche Gesellschaft für Internationale Zusammenarbeit (GIZ) GmbH». За підтримки проєкту в Україні розроблено дві ініціативи: у 2011 році створено ініціативу для історичного центру Львова, а у 2015 році - для історичного центру Чернівців. У кожній із цих ініціатив наявні проєкти та актуальні пропозиції різних підрозділів міських рад, громадських організацій, експертів та громадськості, які були об'єднані як територіально, так і тематично. 32018 року у проєкті беруть участь Львів, Чернівці, Вінниця, Житомир, Полтава та Подільський район Києва.

Перші спроби розробки концепції «розумного» міста почалися в період 
економічної кризи 2008 року. Тоді корпорація IBM (Міжнародна корпорація корпоративних машин) створила концепт, який був частиною ініціативи компанії Smarter Planet (Розумніша планета). Сьогодні IBM $\epsilon$ потужною американською технологічною та консалтинговою корпорацією i одним із найбільших роботодавців у світі. До початку 2009 року цей концепт поширився світом. Було запропоновано вмонтувати смарттехнології в уже функціонуючі міста. Ідею «розумних» міст підтримали лідери країн та окремих міст, а також численні міжнародні установи і організації: Світовий банк, Організація економічного співробітництва та розвитку, Європейський Союз, Європейське інноваційне партнерство, Свропейський фонд регіонального розвитку, Міжнародна організація зі стандартизації, Міжнародний союз електрозв’язку та iнші.

Розумне місто (Smart City) - це ефективна інтеграція фізичних, цифрових i людських систем у штучному середовищі заради сталого, благополучного i всебічного майбутнього для громадян. Таке визначення надано Британським інститутом стандартів British Standards Institution (BSI) [3].

Експерт у сфері урбаністики Білл Хатчінсон запропонував свою класифікацію «розумних» міст версій 1.0, 2.0 і 3.0:

- у «розумному» місті 1.0 немає загальної стратегії, автоматизація торкнулася окремих не пов'язаних між собою компонентів;

- у версії 2.0 ведеться об'єднання і взаємозв'язок раніше незалежних ініціатив та максимально великої кількості різних джерел інформації;

- версія 3.0 передбачає, що об’єднання всіх компонентів завершено, а вся інфраструктура міста буквально просякнута інтелектуальними системами та технологіями [4].

«Smart City» або «розумне» місто - це концепція інтегрованого урбаністичного розвитку, що передбачає наявність розгалуженої інфраструктури, сервіси відкритих даних та використання IT-технологій для повсякденного життя та підвищення рівня обслуговування жителів. Можливі моделі «розумних» міст представлені в табл. 2.

Таблиия 2

Моделі «розумних» міст

\begin{tabular}{|c|c|c|}
\hline $\begin{array}{l}\text { № } \\
3 / \Pi\end{array}$ & Тип моделі & Характеристика \\
\hline 1 & $\begin{array}{l}\text { «Інтелектуальне місто» } \\
\text { (intelligent city) }\end{array}$ & $\begin{array}{l}\text { передбачає інноваційний розвиток та реконструкцію міських територій, } \\
\text { наявність компетенцій, які дозволяють створювати та монетизувати } \\
\text { унікальний інтелектуальний капітал }\end{array}$ \\
\hline 2 & $\begin{array}{l}\text { «Цифрове місто» } \\
\text { (digital city) }\end{array}$ & $\begin{array}{l}\text { функціонує на основі збору відкритих даних (big data), на підставі яких } \\
\text { приймаються рішення. Модель потрібно розглядати } 3 \text { позиції обробки } \\
\text { даних і розподілу інформації }\end{array}$ \\
\hline 3 & $\begin{array}{l}\text { «Стале місто» } \\
\text { (sustainable city) }\end{array}$ & $\begin{array}{l}\text { орієнтоване на впровадження енергоефективних заходів та екологічних } \\
\text { технологій }\end{array}$ \\
\hline 4 & «Техносіті» (technocity) & забезпечує якість логістичної та транспортної інфраструктури \\
\hline 5 & $\begin{array}{l}\text { «Місто добробуту» } \\
\text { (well-being city) }\end{array}$ & $\begin{array}{l}\text { високотехнологічне, ефективне місто, яке працює на випередження } \\
\text { критичних ситуацій, орієнтоване на впровадження технологій, які } \\
\text { слугують засобом підвищення привабливості для місцевих жителів та } \\
\text { бізнесу за рахунок кліматичних, культурних і технологічних переваг }\end{array}$ \\
\hline
\end{tabular}

Джерело: систематизовано авторами за [12, с. 49-50] 
Витрати на ініціативи «розумних» міст у світі у 2020 р. були найбільшими у США - вагомому регіональному ринку, який складає близько $26 \%$ загальносвітових витрат (рис. 2). Загальні ж світові витрати (місцеві бюджети, фінансування компаній та приватних осіб) на проєкти «розумних» міст можуть перевищити у 2025 р. 1 трлн дол США [12].

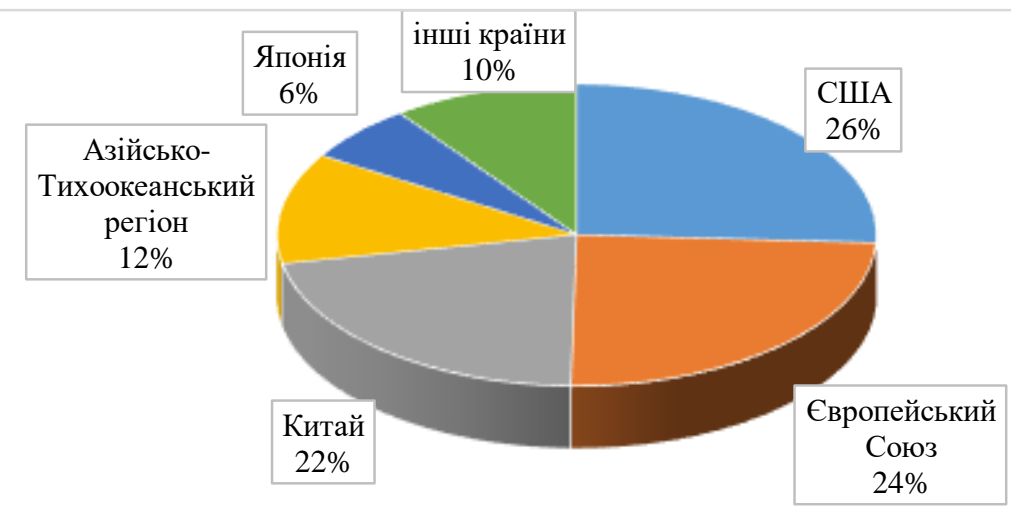

Рис. 2. Географічний розподіл витрат на ініціативи розбудови «розумних» міст у світі у 2020 році, \%

Джерело: побудовано авторами за [12]

Рейтинг міст світу за Smart Cities Index, де впроваджуються технології Smart City, складається різними незалежними компаніями: Juniper Research спільно 3 Intel, Forbes, PwC, Juniper Research i EasyPark. У рейтингу аналізується рівень розвитку 165 міст із 80 країн у дев'яти вимірах, які вважаються ключовими для створення розумного і стійкого міста: людський капітал (розвиток, залучення та виховання талантів), соціальна згуртованість (консенсус між різними соціальними групами, групи в місті), економіка, довкілля, управління, міське планування, міжнародна діяльність, технології, мобільність (транспорт, зручний доступ отримувачів до суспільних послуг).

У рейтингу Smart Cities Index перші місця займають Нью-Йорк, Лондон, Париж, Токіо, Рейк'явік (табл. 3).

Проте, всі ці міста, як і раніше, стикаються 3 проблемою соціальної безпеки, яка $є$ вагомою складовою національної безпеки. Це відображає той факт, що багато міст, які мають високий економічний та технологічний рівень, у той самий час $є$ соціально нерівними і це призводить до проблем між різними прошарками суспільства.

У повний рейтинг 100 технологічних міст увійшло й одне українське Київ, який зайняв всього лише 92 сходинку рейтингу [15].

У Європі створено систему мапування розумних проєктів у різних європейських містах (smartcities-infosystem.eu), яка дає можливість фільтрування за містами, сферами розумних рішень (інформаційнокомунікаційні технології, енергетика, транспорт і мобільність) та програмою, у рамках якої здійснюється фінансування (карта «Інформаційна система «розумних» міст») [12, с. 353]. 
Таблиия 3

Топ-5 міст у рейтингу Smart Cities Index в світі за 2020 рік

\begin{tabular}{|c|c|c|}
\hline $\begin{array}{l}\text { Номер } \\
\text { у рей- } \\
\text { тингу }\end{array}$ & $\begin{array}{c}\text { Місто } \\
\text { (країна) }\end{array}$ & Характеристика \\
\hline 1 & $\begin{array}{c}\text { Нью- } \\
\text { Йорк } \\
\text { (США) }\end{array}$ & 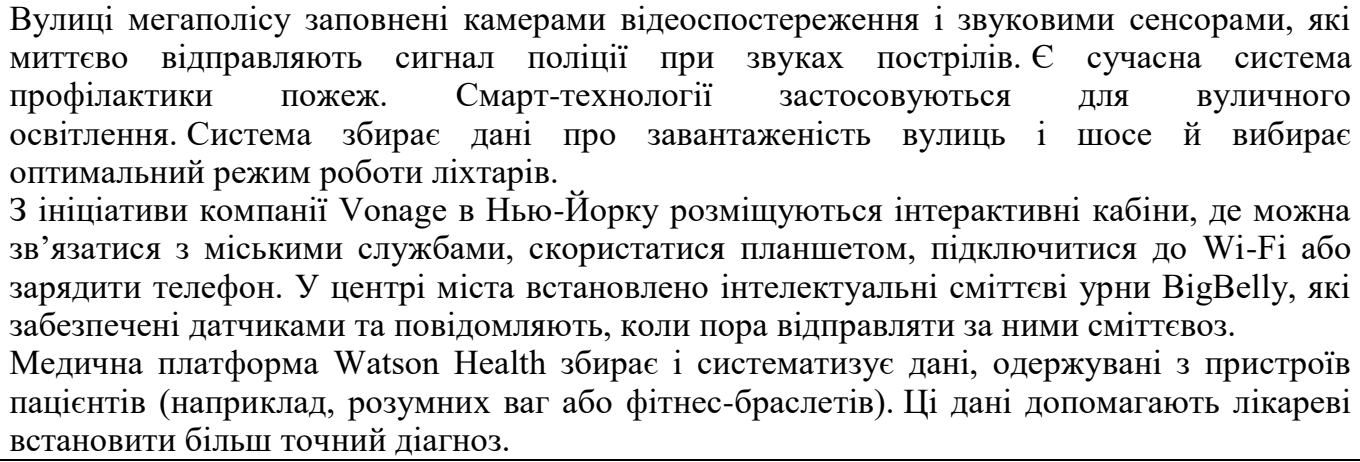 \\
\hline 2 & $\begin{array}{c}\text { Лондон } \\
\text { (Великоб- } \\
\text { ританія) }\end{array}$ & $\begin{array}{l}\text { Лондон був серед перших міст Європи, які зіткнулися з колапсами через затори й нестачі } \\
\text { паркувальних місць. У } 2002 \text { році відбулася транспортна реформа, в ході якої встановили } \\
\text { плату за в’їд у місто, створили мережу перехоплювальних стоянок і замінили систему } \\
\text { автобусного сполучення. } \\
32014 \text { року працюють «розумні» парковки. В місті створили додаток-навігатор: можна } \\
\text { побудувати свій маршрут, і він підбере оптимальні види транспорту. } 32002 \text { року діє } \\
\text { система платежів за перевантаженість доріг, яка зараз уже стала повністю цифровою } \\
\text { (водій платить за право користуватися автомобілем у транспортно-завантаженій зоні в } \\
\text { будні дні). Великобританія - лідер у сфері участі жителів у прийнятті загальноміських } \\
\text { рішень. На інтернет-порталах кожен може обговорити проблеми або отримати необхідну } \\
\text { інформацію. } \\
\text { Система освіти спрямована на підвищення цифрової грамотності населення. Інтернетом у } \\
\text { Лондоні може скористатися кожен, адже класичні ящики для таксофонів на вулицях } \\
\text { перетворені в точки доступу Wі-Fі. Лондон позиціонується як центр для розвитку } \\
\text { талантів в області цифрових технологій та інноваційних послуг і вважається одним із } \\
\text { кращих із точки зору зручності ведення бізнесу. }\end{array}$ \\
\hline 3 & $\begin{array}{c}\text { Париж } \\
\text { (Франція) }\end{array}$ & $\begin{array}{l}\text { Влада Парижа, починаючи з } 2015 \text { року, впровадила в соціальне і громадське життя міста } \\
\text { новітні інформаційні та комунікаційні технології. Згідно } 3 \text { планом інноваційного } \\
\text { розвитку міста, в усіх громадських місцях у Парижі доступний безкоштовний Wi-Fi. } \\
\text { У Парижі з’явилася можливість пересування по місту будь-яким із активних і } \\
\text { екологічних способів: пішки, на електрокарі, на велосипеді. } \\
\text { Помітно зменшилася кількість автомобілів на вулицях міста шляхом розвитку практики } \\
\text { спільного водіння, а також появі додаткових місць для коворкінгу. Надана можливість } \\
\text { оплачувати послуги паркування за допомогою мобільного телефону. }\end{array}$ \\
\hline 4 & $\begin{array}{c}\text { Токіо } \\
\text { (Японія) }\end{array}$ & $\begin{array}{l}\text { Система «розумних» парковок міста і велика мережа точок Wi-Fi дозволила обійти інші } \\
\text { smart-міста в рейтингу. Зовсім нещодавно місто задихалося від смогу і пробок, у 1970-і } \\
\text { роки дорожні поліціянти працювали виключно в кисневих масках. А сьогодні це } \\
\text { мегаполіс хмарочосів, з чистим повітрям, розвиненим транспортом і передбачуваним } \\
\text { автомобільним графіком. } \\
\text { «Розумний» транспорт тут стає синонімом «розумного» міста. Одним із головних } \\
\text { чинників прискореного розвитку Токіо став бурхливий розвиток швидкісного } \\
\text { залізничного сполучення між центром і навколишніми містами. } \\
\text { Мережа залізниць у Токіо - це система швидкісних і звичайних магістралей, з’єднаних } \\
\text { інтермодальними станціями. Кожна така станція - мікромісто з житловими будинками, } \\
\text { офісами, торговельними центрами, готелями та підприємствами сфери послуг. } \\
\text { Крім того, в декількох милях від міста розташовується екомістечко, побудоване } \\
\text { компанією Рапазопіс. У містечку викиди вуглецю дорівнюють нулю, а } \\
\text { електропостачання відбувається за рахунок використання відновлюваних джерел енергії. }\end{array}$ \\
\hline 5 & $\begin{array}{l}\text { Рейк'явік } \\
\text { (Ісландія) }\end{array}$ & $\begin{array}{l}\text { Столиця Ісландії заслужено носить титул «розумного» міста. До послуг } 123000 \text { жителів } \\
\text { Рейк’явіка широкий спектр високих технологій і найшвидший у світі інтернет. Жителі за } \\
\text { допомогою сайту Better Reykjavik можуть пропонувати свої ідеї щодо поліпшення міста, } \\
\text { обговорювати ї і вибирати кращі. } \\
\text { Мережа оптоволоконних кабелів забезпечує величезну швидкість передачі даних - } 500 \\
\text { мегабіт у секунду (середній показник у промислово розвинених країнах - всього } \\
3,5 \text { Мбіт / с). }\end{array}$ \\
\hline
\end{tabular}


В Україні також є успішні приклади впровадження інтелектуальноінформаційних рішень на місцях: цифрові системи управління дорожнім рухом, «розумне» вуличне освітлення та громадський транспорт, безготівкові розрахунки, єдиний квиток для міського громадського транспорту, електронний запис до лікаря та ін. Ці ініціативи влади підвищують прозорість надання послуг, привабливість міст для життя та ведення бізнесу, a, отже, мають бути запроваджені по всій країні. Найактивніше концепція інтегрованого розвитку розвивається у Києві, Львові, Харкові, Вінниці, Дніпрі, Одесі, ІваноФранківську. Загалом близько 15 міст в Україні тією чи іншою мірою розбудовують цю концепцію, впроваджуючи «розумні» рішення.

Але, в цілому, міста нашої держави знаходяться на початку шляху до «розумного» міста версії 1.0. По всій Україні можна знайти приклади окремих сервісних проєктів, які вписуються в концепцію «розумного» міста. У столиці та великих містах України жителі контролюють споживання й оплачують комунальні платежі через «особисті» кабінети, у великих містах працює сервіс пошуку маршрутів громадського транспорту EasyWay. В Україні впроваджена система Е-здоров'я, зокрема, системи онлайн-запису на візит до лікаря та телемедичні послуги [17].

У Києві популяризацію ідей розумного міста забезпечує інтелектуальнотехнологічна платформа Kyiv Smart City, на якій є посилання на сервіси 3 послугами та відомостями про міське господарство столиці. Платформа Куіv Smart City має свою структуру (табл. 4).

\section{Структура інтелектуально-технологічної платформи Kyiv Smart City}

\begin{tabular}{|c|c|c|}
\hline $\begin{array}{l}\text { № } \\
\text { 3/ח }\end{array}$ & Назва цифрового сервіса & Характеристика складової \\
\hline 1 & «Відкритий бюджет» & $\begin{array}{l}\text { Інформаційно-аналітична система «Майно», портал відкритих даних, } \\
\text { громадський бюджет, електронні державні закупівлі, електронний запис } \\
\text { до дитячого садочка, онлайн запис до лікаря, система інформування киян, } \\
\text { реєстр домашніх тварин. }\end{array}$ \\
\hline 2 & Kyiv Smart City School & Освітня платформа нового зразка. \\
\hline 3 & Kyiv Smart City Hub & $\begin{array}{l}\text { Суспільний центр, який допомагає розвивати міські проєкти, надихає } \\
\text { лідерів думок та консолідує різних агентів змін. }\end{array}$ \\
\hline 4 & $\begin{array}{l}\text { Kyiv Smart City Urban } \\
\text { Atlas }\end{array}$ & $\begin{array}{l}\text { Детальний геопросторовий план із функцією збору та аналізу інформації } \\
\text { щодо його інфраструктури та впровадження на основі цих даних } \\
\text { відповідних управлінських рішень. }\end{array}$ \\
\hline 5 & $\begin{array}{l}\text { Kyiv Smart City Безпечне } \\
\text { місто }\end{array}$ & $\begin{array}{l}\text { Проєкт «Безпечне місто» створений задля посилення безпеки киян, } \\
\text { контролю роботи комунальних служб та управління трафіком у місті. Вже } \\
\text { зараз функціонує система розпізнавання облич і номерів автомобілів. }\end{array}$ \\
\hline 6 & $\begin{array}{c}\text { Kуiv Smart City } \\
\text { Соціальний проєкт «He } \\
\text { купуй - візьми з } \\
\text { притулку» }\end{array}$ & $\begin{array}{l}\text { Соціальна кампанія була запущена, аби популяризувати серед громадян } \\
\text { тему адаптації та допомогти котам і собакам знайти люблячих господарів. } \\
\text { Проєкт створено завдяки співпраці міської ініціативи Kyiv Smart City та } \\
\text { київської міської клініки ветеринарної медицини. }\end{array}$ \\
\hline 7 & Kyiv Smart City Е-квиток & Єдиний проїзний документ у громадському транспорті Києва. \\
\hline 8 & $\begin{array}{l}\text { Kyiv Smart City } \\
\text { Безконтактний прохід у } \\
\text { метро }\end{array}$ & $\begin{array}{l}\text { Завдяки спільним зусиллям Київської міської державної адміністрації та } \\
\text { ініціативи Kуіv Smart Сity Київ став одним із міст у світі, після Лондона, } \\
\text { Чикаго, Бухареста, де поїздки на метро можна оплачувати за допомогою } \\
\text { безконтактних банківських карток. }\end{array}$ \\
\hline
\end{tabular}

Джерело: складено авторами за [2]

Kyiv Smart City об’єднує киян, бізнес-активістів та владу міста задля 
розвитку «розумної» міської інфраструктури. Робота ініціативи базується на принципах відкритих даних, «розумного» використання цифрових послуг та прозорого управління.

Заслуговує на увагу складова Kyiv Smart City Urban Atlas. Подібні атласи вже мають міста у 28 країнах Свропи. Київ першим зі Східної Свропи поповнив цей список. Атлас дозволяє спрогнозувати рівень росту забудови міста та його озеленення, а також створити температурну карту. Також він дає можливість виявити так звані міські острови тепла - райони, які найбільше нагріваються через високий рівень забруднення повітря.

Із Києвом за рівнем впровадження інтелектуально-технологічних проєктів активно конкурує Вінниця. Система «Розумне місто» почала діяти у Вінниці з 2011 року. Тоді на офіційному сайті міської ради було запроваджено електронну мапу звернень громадян. Сервіс дозволяв городянам залишати повідомлення для муніципальних служб про локальні проблеми на околицях Вінниці. У конкурсі «розумних» міст, який проводився в рамках Kyiv Smart City Forum, що відбувся у 2020 р., Вінниця стала переможцем у номінації «Найкраще Smart безпечне місто». Цьому у великій мірі посприяла Концепція інтегрованого розвитку м. Вінниці до 2030 року [13]. Цей документ $\epsilon$ путівником міського розвитку Вінниці до 2030 року та рамковими умовами для інших міських програм стратегій у різних сферах.

Ще одна важлива для інтегрованого розвитку міст платформа - проєкт Dosvit, який дозволяє містам створити сучасні інвестиційно привабливі вебсайти та під'єднати до них будь-які додатки, наприклад, бюджет участі, відкритий бюджет, мапу комунальних підприємств, опитування громадян тощо. Платформа Dosvit побудована на сучасних технологіях React та GraphQL [1].

Перешкоди повноцінного інтегрованого розвитку українських міст вбачаються найбільше у сфері зв'язку та інформатизації. Зокрема, третє покоління мобільного зв'язку (3G) дозволяє задовольнити більшу частину потреб користувачів: перегляд сайтів, спілкування в соціальних мережах i месенджерах, online-ігри, навігація, завантаження додатків, перегляд відео. Але проблеми виникають при онлайн перегляді відео у високій роздільній здатності та передачі великих масивів інформації. Із цими запитами вже чудово справляються мережі 4G. Концепція Smart City вимагає впровадження мережі покоління 5G, у якій швидкість передачі даних не є основним параметром. На перший план виходять суцільне покриття територій і доступ до інтернету у важкодоступних місцях. Ще однією вимогою $є$ безперебійна одночасна робота в мережі величезного числа пристроїв.

Основні стратегічні цілі інтегрованого розвитку європейських країн, визначені Лейпцизькою хартією «Міста Свропи на шляху сталого розвитку», створюють підгрунтя для розробки концептуальних рішень інтегрованого розвитку міст в Україні.

На нашу думку, основною метою стратегії ефективного управління міст $\epsilon$ підвищення стандартів проживання, стійкості та надійності функціонування системи житлово-комунального господарства, стандартів якості життя 
населення міст, раціонального використання засобів муніципальних бюджетів, оздоровлення фінансової ситуації та створення умов для вкладення інвестицій (табл. 5).

Табличя 5

\section{Концептуальні рішення інтегрованого розвитку міст}

та її масштабування в Україні

\begin{tabular}{|c|c|c|}
\hline $\begin{array}{c}\text { Основна мета } \\
\text { інтегрованого розвитку } \\
\text { міст }\end{array}$ & $\begin{array}{l}\text { Основний прицип } \\
\text { інтегрованого } \\
\text { розвитку міст }\end{array}$ & Основні рішення концепції \\
\hline \multirow{6}{*}{$\begin{array}{c}\text { Підвищення стандартів } \\
\text { проживання в містах за } \\
\text { рахунок переходу до } \\
\text { довгострокового } \\
\text { планування модернізації } \\
\text { і розвитку міської } \\
\text { інфраструктури як } \\
\text { елементу стратегічного } \\
\text { планування розвитку } \\
\text { міст; створення системи } \\
\text { інформування та } \\
\text { зворотнього зв'язку, } \\
\text { проведення відкритої } \\
\text { політики при управлінні } \\
\text { містом }\end{array}$} & \multirow{6}{*}{$\begin{array}{c}\text { Принцип } \\
\text { позиціонування міст, } \\
\text { при якому планування } \\
\text { та зонування територій } \\
\text { міст нейтралізує } \\
\text { негативний вплив } \\
\text { ринкових сил, } \\
\text { регулююча функція } \\
\text { управління } \\
\text { залишається в } \\
\text { компетенції } \\
\text { муніципального } \\
\text { управління }\end{array}$} & $\begin{array}{l}\text { Гармонізація політики і законодавства } 3 \text { вимогами ЄС } \\
\text { (передбачена Угодою про асоціацію Україна - ЄС), які } \\
\text { стосуються інтегрованого розвитку міст та принципів } \\
\text { міського управління. }\end{array}$ \\
\hline & & 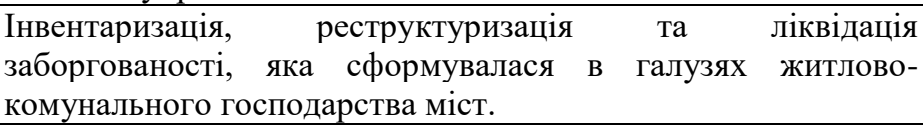 \\
\hline & & $\begin{array}{l}\text { Створення умов для розвитку конкуретних відносин у сфері } \\
\text { управління містами, зміна напрямів фінансових потоків, } \\
\text { перехід до системи персоніфікованих рахунків. }\end{array}$ \\
\hline & & $\begin{array}{l}\text { Впровадження } \quad \text { міжнародних } \\
\text { розвитком міст «Smart City» (ISO-37120, ISO-37101 та інші). }\end{array}$ \\
\hline & & $\begin{array}{l}\text { Розробка національної платформи інтегрованого розвитку } \\
\text { міст - каталогу рішень «Smart City» (на основі апробації } \\
\text { сертифікації) згідно } 3 \text { досвідом Європейської платформи } \\
\text { розумних міст. }\end{array}$ \\
\hline & & $\begin{array}{l}\text { Підтримка інноваційної політики в українських містах } \\
\text { (високотехнологічні інформаційні хаби, промислові та } \\
\text { сервісні центри, парки, кластери та інше) і стимулювання } \\
\text { залучення громадян у розробку міських рішень «Smart City» } \\
\text { (стартап-рух та бізнес-інкубація). }\end{array}$ \\
\hline
\end{tabular}

Джерело: розробка авторів

Висновки. Реалізація завдань інтегрованого розвитку міст передбачає тісне співробітництво та партнерство 3 європейськими товариствами й організаціями, тож маємо надію, що українські міста, запозичивши досвід розвитку міст Європи, в недалекому майбутньому перетворяться на сучасні комфортні місця для проживання 3 постійно зростаючою чисельністю своїх мешканців та їх добробутом, міста, функціонування яких здатне забезпечити завдання сталого розвитку країни.

Українські міста сьогодні не завжди можуть повноцінно використати свій потенціал для інтегрованого розвитку, насамперед, через відсутність сформованого розуміння цієї концепції та стратегічного бачення міського розвитку деякими керівниками міст. Містам потрібно розвивати інституційні можливості для практичної реалізації концепції інтегрованого розвитку міст за рахунок концептуальних рішень, основною метою яких $\epsilon$ підвищення стандартів проживання в містах через перехід на довгострокове планування всіх важливих сфер життєдіяльності міст.

Крім того, велике значення в розвитку міст належить цифровим перетворенням, адже сьогодні нові інституції, кадри, комунікаційні платформи міст України лише формуються. Також у містах немає достатніх ресурсів i можливостей для залучення інвестицій у сферу «Smart City», на що значною мірою впливають національна економічна політика та законодавчі обмеження. 


\section{Список використаних джерел}

1. Dosvit. URL: https://dosvit.org.ua (дата звернення: 21.04.2021).

2. Kyivsmartcity. URL: https://www.kyivsmartcity.com/projects (дата звернення: 14.04.2021).

3. Британский институт стандартов. URL: https://gost-snip.su/razdel/bs (дата звернення: 11.05.2021).

4. Галузі майбутнього: «розумні» міста та будинки. URL: https://mind.ua/publications/20188390 (дата звернення: 11.05.2021).

5. Галушка 3.І., Соболєв В.О. Концепція інтегрованого розвитку міст: необхідність та можливості застосування в Україні. Проблеми системного підходу в економіці. 2019. Вип. 1 (1). С. 80-85. DOI: https://doi.org/10.32782/2520-2200/2019-1-12.

6. Головня О.М. Запровадження інноваційних технологій фінансування соціального розвитку. Економіка, фінанси, менеджмент: актуальні питання науки і практики. 2019. № 7 (47). C. 31-39. DOI: 10.37128/2411-4413-2019-7-4.

7. Офіційний сайт департаменту економічних і соціальних питань $\mathrm{OOH}$. URL: https://www.un.org/development/desa/ru (дата звернення: 11.05.2021).

8. Звіт KPMG: Країни та міста-лідери 3 інноваційних технологій. URL: $\quad$ https://home.kpmg/ua/uk/home/media/press-releases/zvit-kpmg-krainy-tamista-lidery-z-innovatsiynykh-tekhnologiy.html (дата звернення: 11.05.2021).

9. Інтегрований розвиток міст: досвід Берліна та Потсдама для України. URL: https://2030.zhitomir.ua/news-and-events/news/integrovanyy-rozvytok-mistdosvid-berlina-ta-potsdama-dlya-ukrayiny/ (дата звернення: 15.05.2021).

10. Калетнік Г.М., Підвальна О.Г., Колесник Т.В. Діяльність університетів та інноваційних структур за їх участю як чинник сталого місцевого та регіонального розвитку в умовах проведення реформи децентралізації (на прикладі ННВК «Всеукраїнський науково-навчальний консорціум»). Економіка, фінанси, менеджмент: актуальні питання науки і практики. 2018. № 6 (34). С. 7-27.

11. Лейпцизька хартія «Міста Європи на шляху сталого розвитку». Ухвалена з нагоди неформальної зустрічі міністрів з питань міського розвитку і територіальної єдності, проведеної в Лейпцигу 24-25 травня 2007 року. 16 с.

12. Маркевич К., Сіденко В. Smart-інфраструктура у сталому розвитку міст: світовий досвід та перспективи України. Київ: Видавництво «Заповіт». $2021.400 \mathrm{c}$.

13. Проєкт «Концепція інтегрованого розвитку м. Вінниці до 2030 року». Коротка версія. URL: https://www.vmr.gov.ua/SiteAssets/Lists (дата звернення: 18.05.2021).

14. Пронько Л.М. Наслідки проведення реформи децентралізації влади та перспективи розвитку місцевого самоврядування в Україні. Slovak international scientific journal. 2020. № 43, Vol. 3. P. 18-25.

15. Самые инновационные города в мире. URL: https://unsci.com/ru/2019/06/11/samye-innovaczionnye-goroda-v-mire (дата звернення: 
18.05.2021).

16. Чевганова В.Я. Європейський досвід інтегрованого розвитку міст. Економіка і регіон. 2017. № 5. С. 10-14.

17. Чим живуть «найрозумніші міста» нашої планети: Сантадер, Сінгапур i Сонгдо. URL: https://world.segodnya.ua/ua/world/wnews/chem-zhivut-samyeumnye-goroda-nashey-planety (дата звернення: 17.05.2021).

\section{References}

1. Dosvit. dosvit.org. Retrieved from: https://dosvit.org.ua [in English].

2. Kyivsmartcity. kyivsmartcity.com. Retrieved from: https://www.kyivsmartcity.com/projects/ [in English].

3. Britanskiy institut standartov [British Standards Institute]. gost-snip.su. Retrieved from: https://gost-snip.su/razdel/bs [in Russian].

4. Haluzi maybutnoho: «rozumni» mista ta budynky [Industries of the future: «smart» cities and houses]. mind.ua. Retrieved from: https://mind.ua/publications/20188390 [in Ukrainian].

5. Galushka, Z.I, \& Sobolev, V.O. (2019). Kontseptsiya intehrovanoho rozvytku mist: neobkhidnist ta mozhlyvosti zastosuvannya $v$ Ukrayini [The concept of integrated urban development: the need and possibilities of application in Ukraine]. Problemy systemnoho pidkhodu v ekonomitsi - Problems of system approach in economy, 1 (1), 80-85. DOI: https://doi.org/10.32782/2520-2200/20191-12 [in Ukrainian].

6. Holovnia, O.M. (2019). Vprovadzhennya innovatsiynykh tekhnolohiy finansuvannya sotsialnoho rozvytku [Introduction of innovative technologies for financing social development]. Ekonomika, finansy, menedzhment: aktualni pytannia nauky i praktyky - Economics, finance, management: topical issues of science and practical activity, 7 (47), 31-39 [in Ukrainian]. DOI: 10.37128/2411-4413-2019-7-4.

7. Ofitsiinyi sait departamenty ekonomichnykh i sotsialnykh pytan OON [Official site of UN Department of Economic and Social Affairs]. un.org. Retrieved from: https://www.un.org/development/desa/ru [in English].

8. Zvit KPMG: Krayiny ta mista-lidery z innovatsiynykh tekhnolohiy [KPMG Report: Leading Countries and Cities in Innovative Technologies]. home.kpmg/ua. Retrieved from: https://home.kpmg/ua/uk/home/media/press-releases/zvit-kpmgkrainy-ta-mista-lidery-z-innovatsiynykh-tekhnologiy.html [in English].

9. Intehrovanyy rozvytok mist: dosvid Berlina ta Potsdama dlya Ukrayiny [Integrated urban development: the experience of Berlin and Potsdam for Ukraine]. zhitomir.ua. Retrieved from: https://2030.zhitomir.ua/news-andevents/news/integrovanyy-rozvytok-mist-dosvid-berlina-ta-potsdama-dlya-ukrayiny/ [in Ukrainian].

10. Kaletnik, G.M., Pidvalna, O.G., \& Kolesnik, T.V. (2018). Diialnist universytetiv ta innovatsiinykh struktur za yikh uchastiu yak chynnyk staloho mistsevoho ta rehionalnoho rozvytku $\mathrm{v}$ umovakh provedennia reformy detsentralizatsii (na prykladi NNVK «Vseukrainskyi naukovo-navchalnyi konsortsium») [Activities of universities and innovation structures for their 
participation as factor of sustained local and regional development in condition of the of reform of decentralization (at the example of the NNVC «All-Ukrainian Scientific and Education Consortium»)]. Ekonomika, finansy, menedzhment: aktualni pytannia nauky i praktyky - Economics, finance, management: topical issues of science and practical activity, 6 (34), 7-27 [in Ukrainian].

11. Leiptsyzka khartiia «Mista Yevropy na shliakhu staloho rozvytku» [Leipzig Charter "Cities of Europe on Sustainable Development»]. Ukhvalena $z$ nahody neformalnoi zustrichi ministriv $z$ pytan miskoho rozvytku $i$ terytorialnoi yednosti, provedenoi v Leiptsygu 24-25 travnia 2007 roku-Adopted on the occasion of the Informal Meeting of Ministers for Urban Development and Territorial Unity held in Leipzig on 24-25 May 2007 [in Ukrainian].

12. Markevich, K., \& Sidenko, V. (2021). Smart-infrastruktura u stalomu rozvytku mist: svitovyi dosvid ta perspektyvy Ukrainy [Smart infrastructure in sustainable urban development: world experience and prospects of Ukraine]. Kyiv: Vydavnytstvo «Zapovit» [in Ukrainian].

13. Proiekt «Kontseptsiia intehrovanoho rozvytku m. Vinnytsi do 2030 roku» [Project «Concept of integrated development of Vinnytsia until 2030»]. (n.d.). vmr.gov.ua. Retrieved from: https://www.vmr.gov.ua/SiteAssets/Lists [in Ukrainian].

14. Pronko, L.M. (2020). Naslidky provedennia reformy detsentralizatsii vlady ta perspektyvy rozvytku mistsevoho samovriaduvannia $v$ Ukraini [Consequences of the decentralization reform and prospects for the development of local selfgovernment in Ukraine]. Slovak international scientific journal, 43, 3, 18-25 [in English].

15. Samye innovatcionnye goroda $\mathrm{v}$ mire [The most innovative cities in the world]. un-sci.com/ru. Retrieved from: https://un-sci.com/ru/2019/06/11/samyeinnovaczionnye-goroda-v-mire [in Russia].

16. Chevganova, V.Ya. (2017). Yevropeiskyi dosvid intehrovanoho rozvytku mist [European experience of integrated urban development]. Ekonomika i rehionEconomy and region, 5, 10-14 [in Ukrainian].

17. Chym zhyvut «nairozumnishi mista» nashoi planety: Santader, Sinhapur i Sonhdo [What do the «smartest cities» of our planet live in: Santander, Singapore and Songdo]. world.segodnya.ua. Retrieved from: https://world.segodnya.ua/ua/world /wnews/chem-zhivut-samye-umnye-goroda-nashey-planety [in Ukrainian].

\section{Відомості про авторів}

ГОЛОВНЯ Олена Михайлівна - доктор економічних наук, доцент кафедри менеджменту зовнішньоекономічної діяльності, готельно-ресторанної справи та туризму, Вінницький національний аграрний університет (21008, м. Вінниця, вул. Сонячна, 3, e-mail: ellens @ meta.ua).

КОНДРАТОВА Марина Володимирівна - кандидат педагогічних наук, директор Відокремленого структурного підрозділу «Немирівський фаховий коледж будівництва, економіки та дизайну Вінницького національного аграрного університету» (22800, м. Немирів, вул. Гімназійна, 29, e-mail: kondratovamarina960@gmail.com). 
GOLOVNYA Olena - Doctor of Economic Sciences, Associate Professor of the Department of International Management, Hotel and Restaurant Business and Tourism, Vinnytsia National Agrarian University (21008, Vinnytsia, 3, Soniachna Str., e-mail: ellens@ @eta.ua).

KONDRATOVA Maryna - Candidate of Pedagogical Sciences, Director of the Separate Structural Subdivision «Nemyriv Professional College of Construction, Economics and Design of Vinnytsia National Agrarian University» (22800, Nemyriv, 29, Gymnasium Str., e-mail: kondratovamarina960@ gmail.com).

ГОЛОВНЯ Елена Михайловна - доктор экономических наук, доцент кафедры менеджмента внешнеэкономической деятельности, гостиничноресторанного дела и туризма, Винницкий национальный аграрный университет (21008, г. Винница, ул. Солнечная, 3, e-mail: ellens@ meta.ua).

КОНДРАТОВА Марина Владимировна - кандидат педагогических наук, директор Обособленного структурного подразделения «Немировский профессиональный колледж строительства, экономики и дизайна Винницкого национального аграрного университета» $(22800$, г. Немиров, ул. Гимназическая, 29, e-mail: kondratovamarina960@gmail.com).

УДК 004:338.488.2:640.43

DOI: $10.37128 / 2411-4413-2021-3-13$

ДІДЖИТАЛІЗАЦІя ЯК ОСНОВНИЙ ФАКТОР РОЗВИТКУ ІНДУСТРІї ГОСТИННОСТІ У KPAÏHAX ЄВРОСОЮЗУ
ДЖЕДЖУЛА О.М., доктор педагогічних наук, професор, завідувачка кафедри математики та інформаційних технологій

ВОЛОНТИР Л.О., кандидат технічних наук, доцент кафедри комп'ютерних наук та економічної кібернетики, Вінницький національний аграрний університет (м. Вінниця)

У статті розглянуто основні тендениії розвитку ринку індустрії гостинності у країнах Євросоюзу. Аналітичний огляд наукових джерел дозволив виокремити серед них такі: поглиблення спеціалізації готельної ци ресторанної пропозицій; створення міжнародних готельних і ресторанних ланцюгів; розвиток мережі малих підприємств; впровадження в індустрію гостинності нових комп'ютерних технологій; підготовка висококваліфікованого персоналу. Гостра потреба в інноваціях актуалізує проблему впровадження в індустрію гостинності нових комп'ютерних технологій та відповідної підготовки висококваліфікованого персоналу. Визначено основні напрями діджиталізації як основи інновачій в індустрію гостинності: технології розпізнавання образів (облич), використання роботів, віртуальні компаньйони, обладнання номерів «розумною» технікою, використання модулів типу "Онлайн супермаркет турів». Запропоновано класифікацію світових інновацій у готельному бізнесі за видами, нововведеннями та значенням для розвитку гостинного бізнесу. Серед інновацій виокремлено інформаційні та маркетингові 